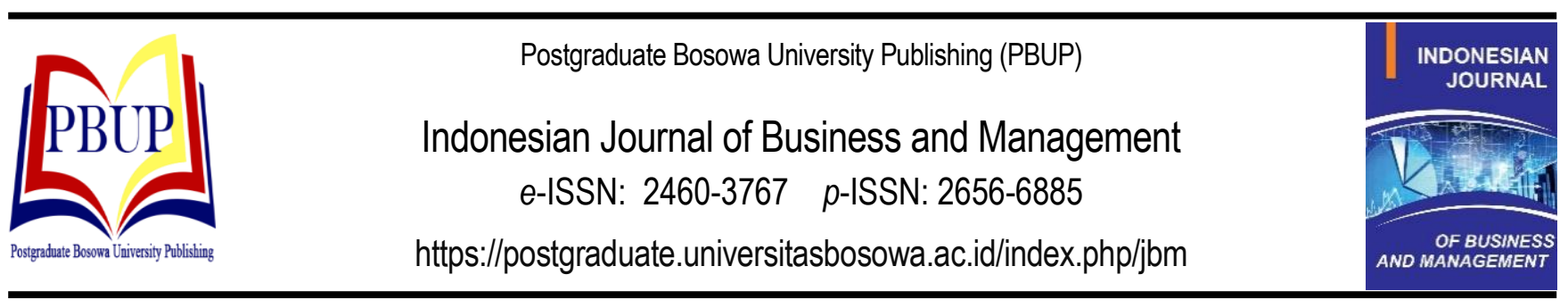

\title{
PENGARUH KREATIVITAS DAN INOVASI TERHADAP KEBERLANGSUNGAN USAHA MELALUI PELAKU USAHA INDUSTRI PENGOLAHAN MAKANAN DAN MINUMAN DI KABUPATEN MAROS
}

\author{
The Effect Of Creativity And Innovation On Business Sustainability Through The Food And Beverage \\ Processing Industry Business ActorsIn Maros District
}

\author{
Hamka $^{1}$, Sukmawati Marjuni ${ }^{2}$, Chahyono ${ }^{2}$ \\ ${ }^{1}$ Balai Diklat Industri Kota Makassar \\ ${ }^{2}$ Program Studi Manajemen Program Pascasarjana Universitas Bosowa \\ Email: khakalere@gmail.com
}

Diterima: 22 September 2021/Disetujui: 12 Desember 2021

\begin{abstract}
ABSTRAK
Untuk menjaga keberlangsungan usaha seyogiaya dilakukan melalui pengembangan ekonomi kreatif. Pe-ngelolaan Usaha industri pengolahan makanan dan minuman melalui penerapan ekonomi kreatif sebagai wujud dari upaya untuk menjaga keberlangsungan usaha melalui kreativitas dan inovasi. Tujuan penelitian ini adalah untuk menganalisis pengaruh kreativitas dan inovasi terhadap pelaku usaha, pengaruh kreativitas, inovasi dan pelaku usaha terhadap keberlangsungan usaha, serta untuk menganalisis pengaruh kreativitas dan inovasi terhadap keberlangsungan usaha melalui pelaku usaha. Penelitian ini merupakan penelitian kuantitatif dengan metode explanatory. Adapun yang menjadi populasi adalah Industri pengolahan makanan dan minuman di Kabupaten Maros sebanyak 476, dengan menggunakan sloving sehingga diperoleh jumlah sampel sebanyak 217. Teknik pengumpulan data melalui penyebaran kuesioner dengan teknik analisis data menggunakan analisis SEM. Hasil penelitian bahwa kreatifitas memberikan pengaruh secara nyata dalam meningkatkan pelaku usaha. Inovasi memberikan pengaruh secara nyata terhadap pelaku usaha. Kreatifitas memberikan pengaruh secara nyata dalam meningkatkan kebelangsungan usaha. Inovasi yang dimiliki maka akan dapat memberikan pengaruh yang nyata dalam meningkatkan keberlangsungan usaha. Pelaku usaha memberikan pengaruh yang nyata dalam meningkatkan keberlangsungan usaha. Pelaku usaha dapat memediasi pengaruh kreatifitas terhadap keberlangsungan usaha dan pelaku usaha dapat memediasi pengaruh inovasi terhadap keberlangsungan usaha pengolahan makanan dan minuman di Kabupaten Maros..
\end{abstract}

Kata Kunci: Kreativitas, Inovasi, Pelaku Usaha, Keberlangsungan Usaha

\begin{abstract}
To maintain business continuity, it should be done through the development of the creative economy. Business management of the food and beverage processing industry through the application of the creative economy as a manifestation of efforts to maintain business continuity through creativity and innovation. The purpose of this study is to analyze the effect of creativity and innovation on business actors, the effect of creativity, innovation and business actors on business continuity, and to analyze the effect of creativity and innovation on business sustainability through business actors. This research is quantitative research with an explanatory method. The population of the food and beverage processing industry in Maros Regency is as many as 476, by using slovin so that a total sample of 217 is obtained. Data collection techniques are through questionnaires with data analysis techniques using SEM analysis. The results of the study show that creativity has a real influence on increasing business actors. Innovation has a real impact on business actors. Creativity has a real influence on increasing business continuity. The innovations that are owned will be able to have a real influence on improving business continuity. Business actors have a real influence on improving business continuity. Business actors can mediate the influence of creativity on business continuity and business actors can mediate the influence of innovation on the sustainability of food and beverage processing businesses in Maros Regency.
\end{abstract}




\section{PENDAHULUAN}

Untuk meningkatkan keberlangsungan usaha pengolahan makanan dan minuman, maka dibutuhkan kreativitas dan inovasi untuk meraih keunggulan dalam bersaing, Keunggulan bersaing menjadi kata kunci terakhir untuk melihat kinerja akhir sebuah bisnis (Man et al., 2002). Seperti dikatakan Menurut Zangwill (1993) yang dikutip oleh Lena et al (2009), tanpa inovasi, perusahaan akan mati. Perusahaan yang melakukan inovasi secara terus-menerus akan dapat mendominasi pasar dan sulit dikejar pesaing untuk ditiru. Akan tetapi perlu diingat banyak produk inovatif yang gagal dipasaran, permasalahannya sederhana karena konsumen tidak menginginkan produk tersebut.

Menurut Cumming (1998) yang dikutip oleh Carmen et al (2009), Inovasi proses mencakup rekayasa ulang proses bisnis, peningkatan operasi internal dan kapasitas. Pentingnya inovasi proses cukup dipahami dengan baik, terutama di perusahaanperusahaan di bawah ancaman karena dapat membantu untuk meningkatkan produktivitas perusahaan. Dari definisi ini dapat dinyatakan bahwa perusahaan harus melakukan inovasi proses seperti merekayasa ulang proses bisnis, peningkatan operasi internal dan kapasitas yang akan berdampak pada produktivitas perusahaan. Sejatinya menurut Zhaou et al., (2005), orientasi pasar adalah fasilitas untuk mendobrak terjadinya kebekuan dalam inovasi, tetapi harus tetap berorientasi kepada konsumen dan pesaing, serta di dalam organisasi ada koordinasi antara fungsi.

Alternatif yang sangat memungkinkan dalam keberlangsungan usaha harus memiliki keunggulan bersaing adalah mencari keunggulan lewat sumberdaya. Kompetensi adalah konsep yang ditawarkan untuk menjawab tantangan tersebut. Kompetensi kewirausahaan menurut Reniati (2013) adalah kesatuan dari pengetahuan (knowledge), keterampilan (skill), dan kemampuan (ability) yang bersifat dinamis yang diperagakan oleh seorang wirausaha/organisasi sehingga terpancarkan dari perilakunya untuk mencapai kesusesan dalam bisnisnya secara berkesinambungan. Perilaku wirausaha dalam perspektif kajian ini lebih menekankan pada kompetensi kewirausahaan; kompetensi peluang, komitmen, dan operasional atas industri pengolahan makanan dan minuman di Kabupaten Maros.

Implikasi keberlangsungan usaha atas kondisi di atas, mengandung arti bahwa pola pikir kreatif sangat diperlukan untuk tetap bertahan di masa yang akan datang, sebuah organisasi/perusahaan harus memiliki kemampuan mengorganisasikan ide-ide multidipliner dan juga kemampuan memecahkan masalah dengan cara-cara di luar kebiasaan. Untuk itu dibutuhkan wirausaha yang memiliki organisasi yang kreatif, agar mereka mampu melakukan inovasi bisnis dan memiliki keunggulan bersaing yang berkelanjutan. Keberlangsungan usaha sangat ditentukan oleh perilaku wirausaha, sedangkan untuk perilaku wirausaha sangat ditentukan oleh kreativitas dan inovasinya. Artinya semakin tinggi kreativitas dan inovasi serta dengan dibarengi semakin tinggi perilaku wirausaha, maka semakin tinggi pula keberlangsungan usaha demikian pula sebaliknya.

Untuk mempertahankan keberlangsungan usaha agar tetap kokoh, maka diperlukan kewirausahaan. Kewirausahaan adalah penerapan kreativitas dan inovasi untuk memecahkan masalah dan upaya memanfaatkan pelaku yang dihadapi setiap hari. Kreativitas adalah kemampuan mengembangkan ide-ide dan menemukan cara-cara baru dalam memecahkan persoalan dan menghadapi peluang. Sedangkan inovasi adalah kemampuan menerapkan kreativitas dalam rangka memecahkan persoalan dan pelaku untuk meningkatkan atau memperkaya kehidupan (Zimmerer, 2008).

Kewirausahaan adalah kemampuan kreatif dan inovatif yang dijadikan dasar, kiat, dan sumber daya untuk mencari pelaku menuju sukses. Adapun inti kewirausahaan adalah kemampuan untuk menciptakan sesuatu yang baru dan berbeda melalui berpikir kreatif dan bertindak inovatif untuk menciptakan pelaku (Suryana, 2013). Kewirausahaan merupakan proses penciptaan sesuatu yang baru (kreasi baru) dan membuat suatu yang berbeda dari yang telah ada (inovasi), tujuannya adalah tercapainya kesejahteraan individu dan nilai tambah bagi masyarakat (Ropke, 2004).

Berdasarkan penjelasan, maka menjadi variabel penelitian dalam kajian penelitian adalah kreativitas, inovasi, perilaku wirausaha, dan keberlangsungan usaha, di mana keberlangsungan usaha diindikasikan dipengaruhi oleh kreativitas dan inovasi melalui perilaku wirausaha yang kompoten. Fokus penelitian adalah industri pengolahan makanan dan minuman di Kabupaten Maros yang mengacu pada BPS adalah suatu kegiatan ekonomi yang melakukan kegiatan mengubah suatu barang dasar secara mekanis, kimia, atau dengan tangan sehingga menjadi barang jadi/setengah jadi, dan atau barang yang kurang nilainya menjadi barang yang lebih tinggi nilainya, dan sifatnya lebih dekat kepada pemakai akhir, serta terdaftar pada dinas Perindustrian dan Perdagangan Kabupaten Maros, dan dinas Koperasi, UKM dan Perdagangan Kabupaten Maros.

\section{METODE}

\section{a. Jenis Penelitian}

Desain Penelitian yang digunakan adalah penelitian eksplanatori, penelitian eksplanatori (explanatory research) adalah penelitian yang bertujuan untuk menganalisis hubungan-hubungan antara satu variabel dengan variabel lainnya atau bagaimana suatu variabel mempengaruhi variabel lainnya. Menurut Singarimbun, Masri dan Effendy (2008) penelitian eksplanatori (explanatory research) merupakan penelitian penjelasan yang menyoroti hubungan kausal antara variabel-variabel penelitian dan menguji hipotesis yang telah dirumuskan sebelumnya, menguji hipotesis penelitian tentang pengaruh kreativitas dan inovasi terhadap keberlangsungan usaha, Pengolahan Makanan dan Minuman di Kabupaten Maros

\section{b. Lokasi Penelitian}


Lokasi dalam penelitian ini tepatnya pada usaha pengolahan makanan dan minuman yang berlokasi di Kabupaten Maros.

\section{c. Populasi dan Sampel}

Populasi dalam penelitian ini adalah Industri pengolahan makanan dan minuman yang ada di Kabupaten Maros dan terdaftar pada Dinas Perindustrian Kabupaten Maros, Dinas Perdagangan Koperasi dan UKM Kabupaten Maros yang berjumlah sebanyak 476 unit. Untuk menentukan sampel maka digunakan rumus slovin sehingga diperoleh sampel sebanyak 217 unit industri pengolahan makanan dan minuman di Kabupaten Maros.

\section{d. Variabel Penelitian}

Variabel penelitian yang dikemukakan dalam penelitian ini dapat dibagi menjadi tiga, yaitu: Variabel bebas (X) dalam penelitian ini meliputi: a. kreativitas (X1), b. inovatif (X2). Kemudian Variabel Terikat (Y) yakni keberlangsungan usaha, serta variabel mediasi (Z) yakni: pelaku usaha.

\section{e. Teknik Pengumpulan Data}

Teknik pengumpulan data yang digunakan dalam penelitian ini adalah: Wawancara yakni dengan menggunakan daftar pertanyaan terstruktur sebagai pedoman di lapangan. Kuesioner, dilakukan dengan cara menggunakan daftar pertanyaan yang mengacuh pada skala likert dengan item pertanyaan yang sifatnya tertutup dan terbuka serta option peringkat terendah diberi skor 1 hingga tertinggi diberi skor 5. Observasi, dilakukan melalui pengamatan berperan serta (participant observation) terhadap objek yang diteliti. Dokumentasi, dilakukan dengan mengumpulkan annual report yang memiliki relevansi dengan fokus penelitian, yaitu berupa data publikasi yang bertalian dengan perkembangan Industri pengolahan makanan dan minuman di Kabupaten Maros.

\section{f. Jenis dan Sumber Data}

Jenis data yang digunakan dalam penelitian ini berupa data kuantitatif seperti angka-angka, skala-skala, tabeltabel, dan sebagainya yang sedikit banyak menggunakan angka-angka atau data-data lainnya yang menunjang penelitian ini, serta data kualitatif berupa data yang tidak dapat diukur dengan angka ataupun ukuran lain. Sedangkan sumber data, yaitu data yang diperoleh melalui kuesioner dan dari sumber lainnya yang ada kaitannya dengan masalah yang akan diteliti dalam penelitian ini, serta sumber data sekunder, yaitu data yang diperoleh dari catatan-catatan, buku-buku, makalah, laporan, arsip dan dokumen-dokumen yang ada kaitannya dengan penelitian ini.

\section{g. Teknis Analisis Data}

Metode analisis yang digunakan dalam penelitian ini adalah structural equation modeling (SEM) dengan menggunakan paket program Lisrel 8.80 dan dengan bantuan software SPSS versi 23. Adapun kriteria pengukurannya yaitu :

1) Absolute Fit Measure, yaitu mengukur model fit secara keseluruhan (baik model struktural maupun model pengukuran secara bersamaan). Kriterianya dengan melihat nilai chi-square, probability, goodness of fit index (GFI), dan root mean square error of approximation (RMSEA).

2) The Likelihood-Ratio Chi Squre Statistic, yaitu tingkat signifikan minimum yang diterima adalah 0,05 dan 0,01 pada pengukuran chi-square, peneliti mencari perbedaan yang non signifcant dikarenakan tes ini diantara matriks actual dan prediksi.

3) Root Mean Square Error of Approximation (RMSEA), yaitu nilai RMSEA menunjukkan GFI yang dapat diharapkan bila model diestimasi dalam populasi, RMSEA dapat digunakan bila nilai chi square signifikan. Nilai yang dibutuhkan agar RMSEA dapat dikatakan fit adalah $<0,08$.

4) Incremental Fit Measures, yaitu ukuran untuk membandingkan model yang diajukan (proposed model) dengan model lain yang dispesialisasikan oleh peneliti.

\section{HASIL DAN PEMBAHASAN}

a. Hasil Penelitian

1) Uji Konfirmtatori Variabel

Uji konfirmatori faktor (Confirmatory factor analysis) merupakan model pengukuran yang dapat dilakukan berdasarkan nilai goodness of fit yang dipersyaratkan oleh Lisrel. Pengujian konfirmatory dalam analisis CFA dengan Lisrel yang terdiri dari model eksogen meliputi kreatifitas dan inovasi.

Uji validitas konstruk eksogen yakni untuk menguji ketepatan/keabsahan masing-masing indikator dalam mengukur variabel kreatifitas dan inovasi, sehingga menurut Kusnendi (2018:120) bahwa hasil uji kebermaknaan masing-masing bobot faktor menunjukkan bobot faktor yang dipersyaratkan sebesar 0,50. Hal tersebut mengandung arti bahwa masing-masing indikator memiliki validitas yang memadai dalam mengukur variabel yang diteliti. Dari hasil uji validitas variabel kreatifitas yang direfleksikan dengan 3 indikator penelitian yang memiliki kisaran loading factor 0,862-0,944 yang masing-masing kisaran loading lebih besar 0,50 .

Hal ini menunjukkan bahwa ketiga indikator penelitian memiliki ketepatan dalam mengukur konstruk inovasi dan selain itu nilai thitung lebih besar dari 1,96. Selain itu inovasi direfleksikan dengan 3 indikator penelitian memiliki nilai loading factor 0,764-0,949 dimana setiap indikator penelitian memiliki nilai loading lebih besar dari 0,50 dan t statistic lebih besar 1,96, hal ini dapat dikatakan bahwa setiap indikator sudah memiliki ketepatan dalam mengkonfirmasi variabel inovasi. Dengan demikian dapat dikatakan bahwa semua indikator yang digunakan memiliki ketepatan dalam mengkonfirmasi variabel eksogen (kreatifitas dan inovasi).

Kemudian akan dilakukan uji reliabilitas yang bertujuan untuk mengukur keandalan indikator-indikator dalam mengukur variabel eksogennya, menurut Kusnandi (2018) bahwa dilihat dari nilai estimasi reliabilitas konstruk diperoleh nilai relibilitas konstruk harus lebih besar 0,70 dan selain itu nilai koefisien variance extracted lebih besar dari 0,50. Dari hasil uji reliabilitas konstruk yaitu kreatifitas 
Pengaruh Kreativitas dan Inovasi Terhadap Keberlangsungan ..... (Hamka, Sukmawati Marjuni, Chahyono)

memiliki nilai reliabilitas 0,928 dengan nilai AVE sebesar 0,812 , sedangkan nilai reliabilitas konstruk inovasi sebesar 0,885 dan nilai AVE sebesar 0,721. Karena nilai reliabilitas konstruk lebih besar dari 0,70 dan AVE lebih besar dari 0,50 maka dapat dikatakan bahwa reliabilitas konstruk sudah andal/reliabel, yang artinya semua indikator penelitian sudah memiliki keandalan atau memiliki konsistensi yang tinggi dalam mengukur variabel kreatiitas dan inovasi.

Setelah dilakukan uji konfirmatory variabel eksogen maka akan dilakukan uji konfirmatori variabel endogen, dimana variabel endogen yang di dalamnya meliputi pelaku usaha dan keberlangsungan usaha. Dimana diperoleh nilai goodness of fit indeks untuk model endogen (model revisi) menunjukkan bahwa GFI, AGFI, CFI, NFI dan RMSEA sudah sesuai dengan nilai cut off value yang dipersyaratkan dalam SEM Lisrel 8.80 sedangkan nilai Chi Square dan $\square$ value sudah mendekati dari nilai cut off value yang dipersyaratkan dalam Lisrel 8.80, sehingga dapat disimpulkan bahwa model endogen (model revisi) sudah memiliki good fit yang artinya model yang digunakan dalam uji konfirmatori sudah berada dalam kategori baik, karena model sudah memiliki kelayakan maka akan dilakukan uji validitas dan reliabilitas.

Sedangkan uji validitas indikator dalam konstruk endogen yang masing-masing untuk variabel pelaku usaha diukur dengan 3 indikator penelitian dan keberlangsungan usaha diukur dengan 3 indikator penelitian. Untuk lebih jelasnya akan disajikan nilai loading factor yang diolah dengan menggunakan Lisrel 8.80, yang direfleksikan dengan 3 indikator penelitian, dimana memiliki kisaran nilai loading factor 0,940-0,952 sedangkan keberlangsungan usaha dengan 3 indikator, masing-masing kisaran loading 0,926-0,936. Karena kisaran loading sudah memiliki kisaran loading lebih besar dari 0,50, hal ini menunjukkan bahwa semua indikator penelitian dalam variabel endogen sudah dapat dikategorikan tepat mengukur variabelnya. Sehingga dapat digunakan untuk proses selanjutnya.

Selanjutnya uji reliabilitas model endogen (peluang usaha dan keberlangsungan usaha) maka diperoleh nilai reliabilitas konstruk yaitu pelaku usaha sebesar 0,964 dan AVE sebesar 0,898 dan nilai reliabilitas konstruk keberlangsungan usaha 0,951 dan AVE sebesar 0,865. Karena nilai reliabilitas konstruk lebih besar dari 0,70 dan AVE lebih besar 0,50 maka dapat dikatakan bahwa indikator penelitian sudah dapat diandalkan dalam mengukur variabelnya. Dengan demikian maka dapat dikatakan bahwa keseluruhan indikator sudah memiliki ketepatan dan keandalan dalam mengkonfirmasi variabelnya untuk digunakan dalam pengujian hipotesis penelitian ini.

2) Analisis Pengujian Hipotesis

Analisis pengujian hipotesis penelitian yang bertujuan untuk menguji pengaruh kreatifitas dan inovasi terhadap keberlangsungan usaha melalui pelaku usaha pada perusahaan industri pengolahan makanan dan minuman di Kabupaten Maros, dimana ringkasan hasil pengujian hipotesis dalam penelitian ini yang dapat disajikan melalui tabel yaitu sebagai berikut :
Ringkasan Hasil Pengujian Hipotesis Penelitian

\begin{tabular}{|c|c|c|c|c|c|c|}
\hline No. & $\begin{array}{l}\text { Hipotesis } \\
\text { Penelitian }\end{array}$ & $\begin{array}{l}\text { Pengaruh } \\
\text { Langsung }\end{array}$ & $\begin{array}{c}\text { Pengaruh } \\
\text { Tidak } \\
\text { Langsung }\end{array}$ & $\begin{array}{c}\text { Total } \\
\text { Pengaruh }\end{array}$ & $\begin{array}{c}\mathrm{T} \\
\text { tabel }\end{array}$ & $\begin{array}{l}\text { Kepu- } \\
\text { tusan }\end{array}$ \\
\hline 1 & $\begin{array}{l}\text { Pengaruh } \\
\text { kreativitas } \\
\text { terhadap } \\
\text { pelaku usaha }\end{array}$ & 0,201 & - & 0,201 & 2,843 & Terbukti \\
\hline 2 & $\begin{array}{l}\text { Pengaruh } \\
\text { inovasi } \\
\text { terhadap } \\
\text { pelaku usaha }\end{array}$ & 0,215 & - & 0,215 & 3,057 & Terbukti \\
\hline 3 & $\begin{array}{l}\text { Pengaruh } \\
\text { kreativitas } \\
\text { terhadap } \\
\text { keberlang- } \\
\text { sungan usaha }\end{array}$ & 0,286 & - & 0,286 & 4,790 & Terbukti \\
\hline 4 & $\begin{array}{l}\text { Pengaruh } \\
\text { inovasi } \\
\text { terhadap } \\
\text { keberlangsu- } \\
\text { ngan usaha } \\
\end{array}$ & 0,137 & - & 0,137 & 2,311 & Terbukti \\
\hline
\end{tabular}

\section{b. Pembahasan}

1) Pengaruh Kreatifitas Terhadap Pelaku Usaha

Temuan dalam penelitian ini mengindikasikan bahwa semakin kreatif seorang wirausaha dengan kegiatan bisnis pengolahan makanan dan minuman maka akan dapat diikuti oleh adanya peningkatan pelaku usaha, sehingga dalam penelitian ini dapat membuktikan bahwa kreatifitas yang dimiliki oleh setiap wirausaha akan dapat diikuti oleh adanya peningkatan pelaku usaha. Oleh karena ini maka perlu ditunjang oleh adanya iklim organisasi, kepemimpinan dan budaya organisasi dalam mengelolah usaha pengolahan makanan dan minuman di Kabupaten Maros.

Penelitian yang dilakukan oleh Purwana, et.al., (2017) yang hasil penelitiannya menemukan bahwa kreatifitas memiliki dampak yang signifikan terhadap perkembangan usaha, sedangkan penelitian oleh Chahyono et al., (2017) kreatifitas memiliki pengaruh langsung dan signifikan terhadap perilaku wirausaha.

2) Pengaruh Inovasi Terhadap Pelaku Usaha

Persepsi wirausaha terkait dengan inovasi organisasi yang sudah dikategorikan baik, alasannya karena wirausaha telah memberikan tanggapan bahwa adanya pemahaman mengenai kesadaran lingkungan usaha yang merupakan hal yang penting dalam menjalankan jenis usaha pengolahan makanan dan minuman di Kabupaten Maros, dan selain itu adanya penentuan arah dan tujuan pengembangan individu dalam satu tim. Temuan dalam penelitian ini memberikan indikasi bahwa inovasi memberikan pengaruh secara nyata dalam meningkatkan pelaku usaha pengolahan makanan dan minuman di Kabupaten Maros, dimana semakin tinggi inovasi maka akan semakin tinggi pula pelaku usaha pengolahan makanan dan minuman di Kabupaten Maros. Penelitian yang dilakukan oleh peneliti yang sejalan dengan penelitian oleh chahyono et al., (2017), dan selain itu menerima hipotesis penelitian yang telah dikemukakan sebelumnya. 
3) Pengaruh Kreatifitas terhadap Keberbalngsungan Usaha

Temuan dalam penelitian yakni pengaruh kreatifitas terhadap keberlangsungan usaha pengolahan makanan dan minuman di Kabupaten Maros, yang menunjukkan bahwa kreatifitas memberikan pengaruh secara nyata dalam meningkatkan keberlangsungan usaha. Hal ini mengindikasikan bahwa semakin kreatif seorang wirausaha maka akan semakin baik pula keberlangsungan usaha pengolahan makanan dan minuman di Kabupaten Maros yang dikelolah. Sehingga dalam penelitian ini yang sejalan dengan penelitian oleh Chahyono, et al., (2017) dan selain itu menerima hipotesis dalam penelitian yang telah dikemukakan sebelumnya.

4) Pengaruh Inovasi Terhadap Keberlangsungan Usaha

Hasil pengujian hipotesis penelitian yaitu pengaruh inovasi terhadap keberlangsungan usaha pengolahan makanan dan minuman di Kabupaten Maros, dimana terkait dari jawaban wirausaha mengenai inovasi maka skor jawaban yang terendah adalah inovasi produk, dimana terkait inovasi produk yang masih perlu ditingkatkan oleh wirausaha adalah produk yang dihasilkan mempunyai nilai kebaruan. Upaya dalam meningkatkan keberlangsungan usaha dalam pengolahan makanan dan minuman di Kabupaten Maros maka setiap wirausaha untuk melakukan inovasi untuk menciptakan ide ide yang kreatif untuk senantiasa menciptakan nilai produk yang baru dengan memanfaatkan teknologi baru.

Kemudian skor yang tertinggi dalam penelitian ini adalah inovasi proses, hal ini perlu dipertahankan oleh wirausaha selama ini yakni dengan mengembangkan informasi akurat mengenai pengembangan nilai dan tujuan inovasi dalam pengembangan usaha pengolahan makanan dan minuman di kabupaten maros. Sehingga dengan analisis data penelitian yang telah dilakukan selama ini, terlihat bahwa inovasi dapat memberikan pengaruh secara nyata dalam meningkatkan keberlangsungan usaha, dimana semakin tinggi kemampuan wirausaha untuk selaku berinovasi dengan jenis usaha yang dikelolah selama ini maka dapat diikuti oleh adanya peningkatan keberlangsungan usaha pengolahan makanan dan minuman di Kabupaten Maros selama ini. Hal ini sejalan dengan penelitian yang dilakukan oleh Chahyono et al., (2017) dan selain menerima hipotesis dalam penelitian yang telah dikemukakan sebelumnya.

5) Pengaruh Pelaku Usaha Terhadap Keberlangsungan Usaha

Persepsi wirausaha mengenai kompetensi operasional terkait dengan pelaku usaha dimana sebagian besar wirausaha memberikan jawaban sudah sesuai, dimana adanya wirausaha untuk selalu memanfaatkan sumber daya untuk kemajuan organisasi, kemampuan untuk mengarahkan tanggung jawab secara efektif kepada karyawan juga kemampuan wirausaha untuk mempertahankan efektifitas operasional melalui sumber daya yang ada. Dari ketiga indikator penelitian maka skor yang terkecil adalah kompetensi operasional, dimana yang dinilai masih perlu ditingkatkan adalah lebih banyak meningkatkan kemampuan dalam memanfaatkan sumber yang ada untuk kemajuan organisasi selama ini Sedangkan skor yang tertinggi adalah kompetensi peluang, dimana hal yang dinilai oleh wirausaha untuk tetap dipertahankan oleh wirausaha adalah lebih mengedepankan jenis produk yang diiinginkan oleh konsumen selama ini.

Hasil penelitian diperoleh temuan bahwa pelaku usaha memberikan pengaruh yang secara nyata dalam meningkatkan keberlangsungan usaha pengolahan makanan dan minuman di kabupaten maros, dimana semakin baik pelaku usaha dalam mengelolah jenis usahanya maka akan memberikan dampak secara nyata dalam meningkatkan keberlangsungan usaha. Hal ini sesuai dengan penelitian oleh Chahyono et al (2017) bahwa pelaku usaha memberikan dampak terhadap keberlangsungan usaha, dengan demikian dalam penelitian ini yang menerima hipotesis penelitian.

6) Pengaruh Kreatifitas terhadap Keberlangsungan Usaha Melalui Pelaku Usaha

Hasil penelitian ini dapat membuktikan bahwa pelaku usaha pengolahan makanan dan minuman di Kabupaten Maros dapat memediasi secara parsial pengaruh kreatifitas terhadap keberlangsungan usaha, alasannya karena baik pengaruh langsungnya maupun pengaruh tidak langsungnya memberikan pengaruh secara signifikan terhadap keberlangsungan usaha pengolahan makanan dan minuman di Kabupaten Maros. Dengan demikian dalam penelitian ini menerima hipotesis yang telah dikemukakan sebelumnya.

7) Pengaruh Inovasi terhadap Keberlangsungan Usaha Melalui Pelaku Usaha

Temuan dalam penelitian ini menunjukkan bahwa pelaku usaha dapat memediasi secara parsial pengaruh inovasi terhadap keberlangsungan usaha pengolahan makanan dan minuman di Kabupaten Maros, alasannya karena baik pengaruh langsung maupun pengaruh tidak langsungnya berpengaruh secara signifikan terhadap keberlangsungan usaha pengolahan makanan dan minuman di Kabupaten Maros. Dengan demikian dari hipotesis dalam penelitian ini dapat diterima/terbukti.

Implikasi hasil temuan penelitian ini bahwa kreativitas lebih dominan terhadap keberlangsungan usaha disebabkan karena pelaku usaha berpendidikan rata-rata SMA ke atas dan rata-rata menjalani usaha di atas dari 2 tahun.

\section{KESIMPULAN DAN SARAN}

Hasil penelitian dapat disimpulkan bahwa kreatifitas dapat memberikan pengaruh secara nyata terhadap pelaku usaha. Pengaruh Inovasi terhadap pelaku usaha pengolahan makanan dan minuman di Kabupaten Maros, dimana dalam penelitian ini dapat membuktikan bahwa inovasi memberikan pengaruh secara nyata terhadap pelaku usaha. Pengaruh kreatifitas terhadap keberlangsungan usaha pengolahan makanan dan minuman di Kabupaten Maros, temuan ini menunjukkan bahwa kreatifitas memberikan pengaruh secara nyata dalam meningkatkan kebelangsungan usaha pengolahan makanan dan minuman di Kabupaten Maros. Pengaruh inovasi terhadap keberlangsungan usaha. 


\section{DAFTAR PUSTAKA}

Carmen. Martti \& Maria. 2009. Innovation and performance in SME furniture industries. An international comparative case study. Marketing Intelligence \& Planning, vol. 27, no. 2, pp. 216-232.

Chahyono, (2017) Pengaruh kreatifitas dan Inovasi sebagai determinasi Perilaku usaha wirausaha terhadap keberlangsungan usaha industri.

Lena Ellitan \& Lina Anatan. 2009. Manajemen Inovasi. Transformasi Menuju Organisasi Kelas Dunia. Bandung : Alfabeta.

Man, T. W. Y., T. Lau, dan K. F. Chan. (2002). "The competitiveness of small and medium enterprises $\mathrm{A}$ conceptualization with focus on entrepreneurial competencies". Journal of Business Venturing, Vol. 17, No. 2, hlm: 123-142.

Man, Thomas, Theresa, Snape, Ed, (2012). Entrepreneurial competencies and the Performance of SMEs: An Investigation Through a Framework of Competitiveness. Journal of Small Business \& Entrepreneurship. Vol.21, Issue 3, P.257-276.

Purwana, D., Rahmi, R., \& Aditya, S. 2017. Pemanfaatan Digital Marketing Bagi Usaha Mikro, Kecil, Dan Menengah (UMKM) di Kelurahan Malaka Sari, Duren Sawit. Jurnal Pemberdayaan Masyarakat Madani (JPMM). Vol 1 (1).

Reniati (2011) Keunggulan Bersaing Melalui Inovasi Bisnis Sebuah Desain: Kreativitas Organisasi, Kompetensi Kewirausahaan dan Orientasi Pasar. Indonesian Journal of Economics and Busines Vol 2, No 2 (2012)

Reniati, (2013). Kreativitas Organisasi dan Inovasi Bisnis. Cetakan (2), Bandung: Alpa Beta.

Ropke, Jochen.2003. Ekonomi Koperasi. Jakarta: Penerbit Salemba Empat.

Singarimbun, Masri \& 4ofian Effendi. (2008). Metode Penelitian Survei, Jakarta: LP3ES.

Suryana. (2014). Kewiraushaan Kiat dan Proses Menuju Sukses. Jakarta: Salemba Empat.

Zimmerer, W. Thomas, and Scarborough M. Norman, (2008). Essensialls of Entrepreneurship and Small Businesss Manajemen-Pengantar Kewirausahaan dan Manajemen Bisnis Kecil, Edisi (5), Edisi Bahasa Indonesia, Jakarta: PT Indeks.

Zhou, K. ., Yim, C.K., dan Tse, D.K., (2005), The Efeect of strategic Orientations on Technology-and MarketBased Breakthrough Innovations. Journal of Marketing. Vol. 69 